\title{
Polysaccharides as Cell Carriers for Tissue Engineering: the Use of Cellulose in Vascular Wall Reconstruction
}

\section{BAČÁKOVÁ ${ }^{1}$, K. NOVOTNÁ ${ }^{1}$, M. PAŘÍZEK ${ }^{1}$}

${ }^{1}$ Department of Biomaterials and Tissue Engineering, Institute of Physiology Academy of Sciences of the Czech Republic, Prague, Czech Republic

Received August 12, 2013

Accepted August 20, 2013

\section{Summary}

Polysaccharides are long carbohydrate molecules of monosaccharide units joined together by glycosidic bonds. These biological polymers have emerged as promising materials for tissue engineering due to their biocompatibility, mostly good availability and tailorable properties. This complex group of biomolecules can be classified using several criteria, such as chemical composition (homo- and heteropolysaccharides), structure (linear and branched), function in the organism (structural, storage and secreted polysaccharides), or source (animals, plants, microorganisms). Polysaccharides most widely used in tissue engineering include starch, cellulose, chitosan, pectins, alginate, agar, dextran, pullulan, gellan, xanthan and glycosaminoglycans. Polysaccharides have been applied for engineering and regeneration of practically all tissues, though mostly at the experimental level. Polysaccharides have been tested for engineering of blood vessels, myocardium, heart valves, bone, articular and tracheal cartilage, intervertebral discs, menisci, skin, liver, skeletal muscle, neural tissue, urinary bladder, and also for encapsulation and delivery of pancreatic islets and ovarian follicles. For these purposes, polysaccharides have been applied in various forms, such as injectable hydrogels or porous and fibrous scaffolds, and often in combination with other natural or synthetic polymers or inorganic nanoparticles. The immune response evoked by polysaccharides is usually mild, and can be reduced by purifying the material or by choosing appropriate crosslinking agents.

\section{Key words}

Natural polymers $\bullet$ Bioartificial tissue replacements $\bullet$ Cell carriers

- Cell therapy • Regenerative medicine

\section{Corresponding author}

L. Bačáková, Department of Growth and Differentiation of Cell Populations, Institute of Physiology, Academy of Sciences of the Czech Republic, Vídeňská 1083, 14220 Prague 4 - Krč, Czech Republic. Fax: +420 29644 2488, +42024106 2488. E-mail: lucy@biomed.cas.cz

\section{Introduction}

Tissue engineering is an advanced biotechnology, defined as "an interdisciplinary field that applies the principles of engineering and the life sciences toward the development of biological substitutes that restore, maintain, or improve tissue function" (Langer and Vacanti 1993). These substitutes consist of two main components, i.e. cells and their carriers. The cell carrier, often referred to as a "scaffold", can be made of purely biological molecules, such as collagen, elastin, fibronectin, laminin, hyaluronic acid and other extracellular matrix (ECM) molecules, of synthetic and inorganic molecules, e.g. synthetic polymers, carbonbased materials, ceramics, metal-based materials, or of various combinations of these materials. The materials should be biocompatible, i.e. non-toxic, non-mutagenic, non-immunogenic and matching the mechanical properties of the replaced tissue. However, in advanced tissue engineering, these materials should not just be passively tolerated by cells, but they should act as analogues of the native ECM, i.e. they should control the extent and the strength of cell adhesion, cell proliferation, cell differentiation and maturation to the desired phenotype, and to proper cell functioning. 
Among the biological polymers, polysaccharides have emerged as promising materials for tissue engineering purposes. Polysaccharides are long carbohydrate molecules of monosaccharide units joined together by glycosidic bonds. Polysaccharides can be classified from several points of view. Polysaccharides composed of only one type of monosaccharide are referred to as homopolysaccharides (homoglycans, e.g. starch, glycogen, cellulose, chitin), and if two or more different types of monomeric unit are present, they are referred to as heteropolysaccharides (heteroglycans, e.g. glycosaminoglycans). Other classification criteria consider the morphology of polysaccharide molecules, which can range from linear to highly branched, or the function of polysaccharides in organisms, which is usually either structure-related or storage-related. The main storage polysaccharides are starch and glycogen, while structural polysaccharides include cellulose, chitin, agar, arabinoxylans and pectins. Some polysaccharides are secreted by bacteria, fungi and algae as an evolutionary adaptation to help them adhere to surfaces and to prevent them drying out. Humans have developed some of these polysaccharides into useful products, e.g. dextran, pullulan, gellan gum and xanthan gum. Polysaccharides can also be sorted by their source (animals, plants, microorganisms), by their electrical charge (neutral, cationic, anionic), by modifications of their molecules (pristine molecules and their derivatives), and particularly by their degradability, which is important in tissue engineering. Ideal scaffolds used in advanced tissue engineering should be constructed from resorbable materials that degrade in the organism and are gradually replaced by natural ECM. However, polysaccharides of non-mammalian origin are often non-degradable or very slowly degradable, and in order to adjust their proper degradability, they need to be physically or chemically modified. The criteria for classifying polysaccharides, with examples for each polysaccharide group, are summarized in Table 1. They are based on the studies by Lee et al. (2009), Baldwin and Kiick (2010), Oliveira and Reis (2011), Ulery et al. (2011), and also on the information available at www.cfs.purdue.edu/class/ f\&n630/pdf_full/yao-polysaccharide-2011.pdf.

Polysaccharides are widely applied in many fields, particularly in the food, pharmaceutical and cosmetic industries, in medicine and in various biotechnologies, such as drug and gene delivery or bioimaging. In tissue engineering, they have been used mainly for experimental purposes, though some of them, e.g. hyaluronan, heparin or alginate, are also approved for clinical application.

The first, more general part of this review is dedicated to the use of polysaccharides in various areas of tissue engineering, and the second more specialized part is focused on the use of cellulose in vascular tissue engineering, including the collective experience of the authors of this article.

\section{Polysaccharides relevant for tissue engineering}

Not all polysaccharides are currently used in tissue engineering, or are suitable for this biotechnology, mainly due to their jelly-like consistency and insufficient mechanical properties. Even polysaccharides applicable in tissue engineering are usually combined with other natural or synthetic polymers, or are reinforced with inorganic particles. In addition, these combinations, together with functionalization and loading with various bioactive molecules, such as adhesion oligopeptides, growth factors and drugs, increase the bioactivity of the scaffolds.

The most relevant polysaccharides for application in tissue engineering, which will be discussed in the following text, are starch, cellulose, chitin and chitosan, pectins, alginate, agar, dextran, pullulan, gellan, xanthan and glycosaminoglycans. Other polysaccharides, namely glycogen, are promising as carriers for delivery of drugs or imaging agents (Filippov et al. 2012). Arabinoxylans are also potential candidates for the controlled release of biomolecules, e.g. insulin (Berlanga-Reyes et al. 2009) or lycopene, i.e. a caroteinoid important in the prevention of chronic diseases such as atherosclerosis, skin cancer, prostate cancer and colon cancer (Hernández-Espinoza et al. 2012). In addition, arabinoxylans, owing to their bound phenolic acids, have been shown to have antioxidant activity (Hromádková et al. 2013, Rivas et al. 2013).

\section{Starch}

Starch is a polymer of glucose which is used as a storage polysaccharide in plants, being found in the form of linear amylose and branched amylopectin. Pure starch microfibers, which could serve as scaffolds for cells in tissue engineering applications, were prepared recently by an electrospinning technique (Kong and Ziegler 2012). However, for these applications, starch has been usually combined with other natural or synthetic polymers in 
order to achieve better mechanical properties and bioactivity of the scaffolds. For example, starch microfibers were combined with collagen I nanofibers in order to construct an ECM equivalent for bone tissue engineering (Tuzlakoglu et al. 2011). As for combinations with synthetic polymers, starch has been blended with polycaprolactone or polylactide for bone tissue engineering (Gomes et al. 2008). Combination with starch enhanced the growth and differentiation of articular chondrocytes on polycaprolactone scaffolds
(Oliveira et al. 2007). Starch/polycaprolactone scaffolds also provided a suitable growth support for macro- and microvascular endothelial cells in vitro (Santos et al. 2007). When loaded with vascular endothelial growth factor (VEGF) or fibroblast growth factor-2 (FGF-2), these scaffolds also promoted the expression of neovascularization mediators such as receptors for VEGF (VEGFR1, VEGFR2) and VEGF itself, in cells colonizing the scaffolds after implantation in vivo into mice (Santos et al. 2013).

Table 1. Classification of polysaccharides.

\begin{tabular}{ll}
\hline Classification criteria $\quad$ Examples \\
\hline
\end{tabular}

\section{Function}

$\begin{aligned} \text { Storage } & \text { starch, glycogen } \\ \text { Structural } & \text { cellulose, chitin, alginate, agar } \\ \text { Secreted } & \text { dextran, pullulan, gellan gum, xanthan gum, welan gum, diutan gum }\end{aligned}$

\section{Chemical composition}

Homoglycans

Heteroglycans

\section{Structure}

\section{Electrical charge}

\section{Source}

Animals

Plants

Non-mammals

Mammals starch, glycogen, cellulose, chitin

agars, alginate, carrageenans, xanthan, gellan, arabinoxylans, glycosaminoglycans

Linear glycosaminoglycans, amylose, cellulose, pectin, alginates, agarose

Branched glykogen, amylopectin, xanthan gum, arabic gum, arabinoxylan

Neutral amylose, amylopectin, cellulose

Anionic alginates, carrageenans, gellan, gum arabic, xanthan

Cationic chitosan

glycosaminoglycans (hyaluronan, heparin, chondroitin sulfate, keratan sulfate, dermatan sulfate, heparan sulfate)

chitin

Higher plants

cellulose, starch

Algae agars, alginates, carrageenans

Microorganisms

gellan gum, xanthan gum

Modification

Pristine

cellulose, alginate, chitin

Derivative carboxymethyl cellulose, propylene glycol alginate, chitosan

Degradability in humans

Degradable

Non-degradable, slowly degradable

dextran, glycogen, glycosaminoglycans

cellulose, chitosan, alginate, agar 


\section{Cellulose}

Cellulose is a structural polysaccharide consisting of a linear chain of several hundred to over ten thousand $\beta(1 \rightarrow 4)$ linked D-glucose units. It was discovered and isolated from green plants by Payen (1838) (for a review, see O'Sullivan 1997). It is the most abundant biopolymer on Earth, synthesized by herbs woody plants, many forms of algae, fungi and some species of bacteria, namely Acetobacter xylinum. Bacterial cellulose is identical to plant cellulose in chemical structure, but it can be produced without contaminant molecules, such as lignin and hemicelluloses, and does not require intensive purification processes. In addition, it is remarkable for its mechanical strength and biocompatibility, and it has therefore often been applied in tissue engineering (for a review, see Helenius et al. 2006, Petersen and Gatenholm 2011). In addition to vascular tissue engineering, which is discussed below, cellulose has also been used for engineering a variety of other tissues, such as bone (Shi et al. 2012a), cartilage (Andersson et al. 2010), skin (Kingkaew et al. 2010), skeletal muscle (Dugan et al. 2013), cardiac muscle (Entcheva et al. 2004) and heart valves (Mohammadi 2011). Cellulose has also been used for constructing nanofibrous three-dimensional carriers for liver cells (Bhattacharya et al. 2012), for encapsulating and immunoisolating Langerhans islets (Risbud et al. 2003), for creating tubes for regenerating damaged peripheral nerves (Kowalska-Ludwicka et al. 2013), and also for creating carriers for delivery and differentiation of mesenchymal stem cells $(\mathrm{Gu}$ et al. 2010) and neural stem cells (Mothe et al. 2013) for neural tissue regeneration. Even lignin, a macromolecule crosslinking different plant polysaccharides including cellulose, induced differentiation of embryonic stem cells into neuroectodermal cells, namely ocular cells and neural cells (Inoue et al. 2013). Cellulose acetate in the form of porous membranes has been applied for constructing a bioartificial renal tubule system (Sato et al. 2005), and in the form of electrospun porous microfibrous three-dimensional scaffolds, for potential urinary bladder reconstruction (Han and Gouma 2006). Microporous scaffolds made of bacterial cellulose and seeded with human urine-derived stem cells supported the formation of a multilayered urothelium, and thus these constructs hold promise for creating tissue-engineered urinary conduits for urinary reconstruction and diversion (Bodin et al. 2010).

\section{Chitin and chitosan}

Chitin is a long-chain polymer of $\mathrm{N}$-acetylglucosamine. It is the main component of the cell walls of fungi, the exoskeletons of arthropods such as insects and crustaceans (e.g. crabs, lobsters and shrimps), the radulas of mollusks, and the beaks and internal shells of cephalopods, including squid and octopus. Chitin itself has been used only relatively rarely for tissue engineering. For example, composite scaffolds containing chitin, pectin and $\mathrm{CaCO}_{3}$ nanoparticles were tested with fibroblasts for potential use in tissue engineering and controlled drug delivery (Kumar et al. 2013). Biodegradable porous glycol chitin-based thermoresponsive hydrogel scaffolds promoted odontogenic differentiation of human dental pulp cells, and thus they proved to be promising materials for dentin regeneration (Park et al. 2013).

However, an important derivative of chitin, used for engineering a wide range of tissues and organs, is chitosan. To date, about 1400 papers concerning chitosan and tissue engineering can be found in the PubMed database. Chitosan is a linear polysaccharide composed of randomly distributed $\beta$-(1-4)-linked D-glucosamine (deacetylated unit) and N-acetyl-D-glucosamine. Chitosan, particularly in the form of nanofibrous scaffolds, in combination with other polymers, ceramic or carbon nanoparticles, growth factors and other bioactive molecules, has been applied for reconstructing almost all tissues, such as bone (Frohbergh et al. 2012), blood vessels (Du et al. 2012), heart valves (Hong et al. 2009), myocardium (Hussain et al. 2013), liver (Wang et al. 2005, Mareková et al. 2013), pancreatic islets (Deng et al. 2011), kidney (Gao et al. 2012), urinary bladder (Drewa et al. 2008), skin (Lin et al. 2013) or the central and peripheral nervous system (Shokrgozar et al. 2011, Hu et al. 2013).

\section{Pectins}

Pectins are a family of complex polysaccharides that contain 1,4-linked $\alpha$-D-galactosyluronic acid residues. They are present in most primary cell walls and in the non-woody parts of terrestrial plants. Due to their simple and cytocompatible gelling mechanism, pectins have recently been exploited for various biomedical applications, including drug and gene delivery, wound healing and tissue engineering (for a review, see Munarin et al. 2012). Nanostructured pectin films deposited on titanium, glass and polystyrene substrates promoted the adhesion, growth and osteogenic differentiation of murine 
preosteoblastic MC3T3-E1 cells and primary rat osteoblasts (Kokkonen et al. 2007, 2008, 2012). Pectin gels, particularly those functionalized with RGDcontaining oligopeptides, which serve as ligands for integrin adhesion receptors, have been proposed as injectable carriers for osteoblasts for bone tissue regeneration, due to their ability to keep immobilized cells viable and differentiating (Munarin et al. 2011). For potential bone tissue engineering, pectins have also been used in combination with other natural and synthetic polymers, such as chitosan (Coimbra et al. 2011) or polylactide (Liu et al. 2004).

\section{Alginate}

Alginate, also called alginic acid, is an anionic polysaccharide distributed widely in the cell walls of brown algae, where through binding with water it forms a viscous gum. Alginate is a linear copolymer with homopolymeric blocks of (1-4)-linked $\beta$-D-mannuronate and its C-5 epimer $\alpha$-L-guluronate residues.

Alginate has been used for engineering and regeneration of almost all tissues in the human organism. It has been widely applied in the form of injectable hydrogels, e.g. for encapsulation and delivery of Langerhans islets (Johnson et al. 2011), ovarian follicles (Tagler et al. 2012) and stem cells for neural tissue engineering (Banerjee et al. 2009), bone tissue engineering (Zhou and $\mathrm{Xu}$ 2011) and skeletal muscle regeneration (Liu et al. 2013). Alginate hydrogel-based scaffolds were also tested for engineering of cartilage (Wan et al. 2011) and intervertebral discs (Renani et al. 2012). In combination with hydroxyapatite, alginate hydrogels were applied for regenerating the osteochondral interface (Khanarian et al. 2012). Alginate hydrogels incorporated with poly(ethylene glycol) molecules and antibodies served for capture of endothelial progenitor cells from human blood (Hatch et al. 2011).

In the form of porous scaffolds, alginate has been used for creating a capillary bed in newly reconstructed tissues (Yamamoto et al. 2010), and in the form of electrospun nanofibrous scaffolds, for constructing vascular replacements containing endothelial cells and smooth muscle cells (SMC) (Hajiali et al. 2011), and for skin tissue engineering (Jeong et al. 2012). Alginate was also a component of scaffolds for heart valve engineering (Hockaday et al. 2012), and in combination with gold nanowires, for cardiac tissue engineering (Dvir et al. 2011).
Agar

Agar is a polysaccharide in red algae, serving as the primary structural support for their cell walls. Agar is a mixture of two components: the linear polysaccharide agarose, and a heterogeneous mixture of smaller molecules called agaropectin. Agarose, the predominant component of agar, is a linear polymer, consisting of a repeating monomeric unit of agarobiose. Agarobiose is a disaccharide containing D-galactose and 3,6-anhydro-Lgalactopyranose. Agaropectin is a heterogeneous mixture of smaller molecules that occur in lesser amounts, and is made up of alternating units of D-galactose and L-galactose, heavily modified with acidic side-groups, such as sulfate and pyruvate (for a review, see McHugh 1987).

Agar is well-known as growth substrate for bacteria and other microbes, though it has also been used for cultivating cells of higher plants in order to develop effective methods for large-scale production of artificial seeds (Al-Hajry et al. 1999). Another well-known application is in testing the migratory potential and invasiveness of various cell types, including cells for tissue engineering (Ramaswamy et al. 2012), stem cells for cell therapies (Sabapathy et al. 2012) and for identifying cancer cells (for a review, see Discher et al. 2005).

Other current applications of agar-based materials are in testing the cytotoxicity of various drugs, chemicals and also artificial materials for tissue engineering (Korkmaz et al. 2007, Verma et al. 2009), and in testing the effects of mechanical loading on cell behavior (Shelton et al. 2003). Foils made of soy agar and collagen gel served as substrates for the deposition of cells by thermal inkjet printing, i.e. an advanced technology developed for tissue engineering ( $\mathrm{Xu}$ et al. 2005). Similarly as alginate, agar can be used for cell encapsulation in tissue engineering applications. Due to its chondrogenic potential, agar was selected to entrap chondrocytes within poly-L-lactide scaffolds (Gong et al. 2007). In combination with gelatin, agar has been used for engineering nucleus pulposus (Strange and Oyen 2012), and in combination with hydroxyapatite and hyaluronic acid, for bone tissue engineering (Wagner et al. 2007). Composite membranes made of agar and type I collagen proved to be promising wound dressings for healing burns or ulcers (Bao et al. 2008). Agar gel, attached to the luminal surface of a microporous acrylate tube, supported the formation of in vivo tissue engineered autologous vascular prosthetic tissues, called "biotubes" 
(Nakayama and Tsujinaka 2014). Agarose was used for neural tissue engineering (Bellamkonda et al. 1995) and as a vocal fold substitute (Choo et al. 2010). Together with hyaluronan and water, agar was used for creating an artificial vitreous humor (Kummer et al. 2007).

\section{Dextran and pullulan}

Dextran is a branched glucan (i.e. a polysaccharide composed of many glucose units) containing chains of varying lengths (from 3 to $2000 \mathrm{kDa}$ ). Dextran is synthesized from sucrose by certain lactic-acid bacteria (Leuconostoc mesenteroides, Streptococcus mutans, Lactobacillus brevis). In medical practice, it is used particularly for its antithrombotic properties. For tissue engineering applications, it has been used in combination with pullulan, another polysaccharide consisting of maltotriose units and produced from starch by the fungus Aureobasidium pullulans. Dextran and pullulan have been applied particularly in vascular and bone tissue engineering. In the form of electrospun nanofibrous scaffolds, dextran and pullulan promoted the development of a stable confluent monolayer of endothelial cells, and also the transition of vascular SMC from proliferative phenotype to quiescent contractile phenotype in vitro (Shi et al. $2012 b)$. In the form of porous scaffolds, dextran and pullulan supported the viability, proliferation, differentiation and function of human endothelial progenitor cells isolated from cord blood (Lavergne et al. 2012). In bone tissue engineering, porous dextran/pullulan scaffolds, pure or supplemented with nanocrystalline hydroxyapatite, induced osteogenic cell differentiation in vitro and the formation of mineralized bone tissue in vivo (Fricain et al. 2013).

\section{Gellan and xanthan}

Gellan and xanthan have been shown to be excellent carriers for growth factors and matrices for several tissue engineering applications. These materials are able to gelify in situ within seconds, to retain large quantities of water, and thus to provide a similar environment to that of natural ECM (Khang et al. 2012, Dyondi et al. 2013). In addition, their mechanical properties can be fine-tuned to mimic the replaced natural tissues. Gellan/xanthan gels loaded with chitosan nanoparticles, basic fibroblast growth factor (bFGF), and bone morphogenetic protein 7 (BMP-7) promoted the differentiation of human fetal osteoblasts. At the same time, these gels showed antibacterial effects against
Pseudomonas aeruginosa, Staphylococcus aureus and Staphylococcus epidermidis, i.e. major pathogens causing the failure of bone implants (Dyondi et al. 2013). Gellan gum was loaded with alkaline phosphatase in order to support enzymatic mineralization of scaffolds for bone tissue engineering (Douglas et al. 2012). Gellan gum also supported the viability of encapsulated cells of the nucleus pulposus, and thus it holds promise in the construction of intervertebral disc replacements (Khang et al. 2012). A xanthan gum derivative was successfully used for encapsulation and delivery of chondrocytes for potential cartilage tissue engineering (Mendes et al. 2012).

\section{Glycosaminoglycans}

Glycosaminoglycans (GAGs) are long unbranched polysaccharides consisting of a repeating disaccharide unit. The general disaccharide unit consists of an N-acetyl-hexosamine and a hexose or hexuronic acid, either or both of which may be sulfated. The only GAG that is exclusively non-sulfated is hyaluronan, and sulfated GAGs include heparin, chondroitin sulfate, dermatan sulfate, keratan sulfate and heparan sulfate. In addition to sulfating, the members of the glycosaminoglycan family vary in the type of hexosamine, hexose or hexuronic acid unit that they contain (e.g. glucuronic acid, iduronic acid, galactose, galactosamine, glucosamine). They also vary in the geometry of the glycosidic linkage (for a review, see Collins and Birkinshaw 2013, Schnabelrauch et al. 2013).

Hyaluronan (also called hyaluronic acid or hyaluronate) is an anionic, non-sulfated GAG, which is an important component of ECM and synovial fluid. As hyaluronan is an important component of cartilage, it has been widely used for cartilage tissue engineering. To date, there are almost 3000 papers in the PubMed database dealing with the role of hyaluronan in cartilage tissue engineering, reconstruction and regeneration. Hyaluronan has been used mainly for engineering articular cartilage (Erickson et al. 2012, Kim et al. 2013), but also for meniscus reconstruction (Zellner et al. 2010), osteochondral defects (Filová et al. 2008, Galperin et al. 2013), tracheal defects (Hong et al. 2012) and intervertebral discs (Park et al. 2012). For these purposes, hyaluronan has been applied in the form of a hydrogel with encapsulated chondrocytes (Filová et al. 2008, Park et al. 2012) or mesenchymal stem cells (Zellner et al. 2010, Erickson et al. 2012, Kim et al. 2013). It is also possible to create hyaluronan fibers of submicron- and 
nano-size by an electrospinning technique (Kim et al. 2013) or hyaluronan-based porous scaffolds (Yan et al. 2013). For constructing these scaffolds, hyaluronan has often been combined with other natural and synthetic polymers, such as collagen I and fibrin (Filová et al. 2008, Hong et al. 2012), silk (Park et al. 2012), chitosan (Chen et al. 2013) or methacrylates (Galperin et al. 2013), and for bone tissue engineering, also with a mineral component, e.g. calcium phosphates (Chen et al. 2013, Galperin et al. 2013). Hyaluronan is also a major component of skin, and it has therefore been applied in dermal tissue engineering (Mineo et al. 2013, Yan et al. 2013). Other tissue engineering applications of hyaluronan include reconstruction of heart valves (Duan et al. 2013), myocardial tissue (Dahlmann et al. 2013), skeletal muscle tissue (Desiderio et al. 2013), and also small-caliber arteries (diameter 2-4 mm). Hyaluronanbased biodegradable vascular grafts implanted into pigs supported spontaneous development of a neoartery segment composed of mature smooth muscle cells (SMC), collagen, and elastin fibers organized in layers and completely covered by endothelial cells on the luminal surface (Zavan et al. 2008). Hyaluronan has also been reported to play an important role in the onset and development of atherosclerosis and other vascular diseases, namely by its stimulatory effects on migration and proliferation of vascular SMC (Vigetti et al. 2008). This behavior of SMC can also lead to stenosis and failure of vascular replacements. However, these negative effects are typical for hyaluronan with low molecular weight (less than $500 \mathrm{kDa}$ ), while native high molecular weight hyaluronan (more than $1000 \mathrm{kDa}$ ) has been reported to have antimigratory and antiproliferative effects on SMC (Kothapalli et al. 2010). Antiproliferative activity of hyaluronan can also be induced by O-sulfonation of hyaluronan molecules (Garg et al. 1999).

The presence of sulfur in the molecules of GAGs is generally associated with antiproliferative effects on SMC. In adult healthy vascular wall, sulfated GAGs keep SMC in quiescent differentiated contractile phenotype (Glukhova and Koteliansky 1995). These effects can also be exploited in vascular tissue engineering. For example, SMC in hybrid vascular grafts, constructed on knitted Dacron grafts using endothelial cells, SMC, fibroblasts and artificial ECM consisting of type I collagen and dermatan sulfate, were predominantly of contractile phenotype after 12-week-implantation into dogs (Ishibashi and Matsuda 1994). Sulfated GAGs also supported endothelialization of vascular grafts and their antithrombogenic properties. Expanded polytetrafluoroethylene (ePTFE) vascular grafts coated with perlecan, i.e. the major heparan sulfate proteoglycan in cell basement membranes, stimulated the growth of endothelial cells and suppressed the adhesion of platelets (Lord et al. 2009). The retention of endothelial cells on poly(carbonate-urea)urethane vascular grafts under shear stress was enhanced by modifying these grafts with a matrix consisting of collagen type IV and dermatan sulfate (Salacinski et al. 2001). Heparin in vascular grafts improved not only their antithrombogenicity, but also the retention of growth factors for endothelial cells, such as vascular endothelial growth factor (VEGF) (Ye et al. 2012) and basic fibroblast growth factor (bFGF) (Pitarresi et al. 2013). In addition, heparin enabled stable attachment of stromal cell-derived factor- $1 \alpha$ (SDF-1 $\alpha)$ to vascular prostheses, which served as a capture molecule for endothelial and smooth muscle progenitor cells from blood (Yu et al. 2012).

Heparin and other sulfated GAGs have also been applied in many other areas of tissue engineering. For example, heparin was used for bioactivation of electroconductive polypyrrole-based scaffolds for bone tissue engineering (Meng et al. 2013) and for synthesis of carbonated apatites, which proved to be more favorable to the proliferation and differentiation of MC3T3-E1 preosteoblasts than apatites prepared by a traditional method (Deng et al. 2013). Heparin was also a component of polymeric scaffolds for neural tissue engineering (Kuo and Wang 2012). In the form of hydrogels, heparin has been used for efficient seeding of chondrocytes on polymeric scaffolds for cartilage tissue engineering (Kim et al. 2012), for modifying scaffolds for liver tissue engineering (Bao et al. 2011) and for encapsulating dermal fibroblasts for skin tissue engineering (Choi and Yoo 2013). Keratan sulfate took part in cornea tissue engineering ( $\mathrm{Wu}$ et al. 2013), and chondroitin and dermatan sulfates in the reconstruction of bone, cartilage and skin (Vandrovcova et al. 2011, for a review, see Schnabelrauch et al. 2013).

\section{Polysaccharides and inflammatory reactions}

Like other biological and artificial materials used in tissue engineering, polysaccharides are associated with a risk of undesirable immune activation of cells and inflammatory reactions. The reaction is usually manifested by expression of immunoglobulin and selectin 
molecules on cells contacting the material. These molecules are e.g. intercellular adhesion molecule-1 (ICAM-1), vascular cell adhesion molecule-1 (VCAM-1) and endothelial-leukocyte adhesion molecule-1 (ELAM-1). Other inflammatory markers include the production of cytokines (e.g. tumor necrosis factors and interleukins), infiltration with leucocytes, lymphocytes and macrophages, foreign body reaction and fibrous encapsulation of the implant. Some polysaccharide-based materials evoke a relatively severe immune reaction. For example, hyaluronan-based scaffolds (Hyalograft $\mathrm{C}$ ) for engineering cartilage for laryngotracheal reconstruction implanted into rabbits induced a foreign body reaction leading to complete degradation of the neocartilage and failure of the implant (Weidenbecher et al. 2007). Intraarticular injections of Hylan G-F 20, a hyaluronan-based synovial fluid replacement, caused an acute inflammatory reaction with the activation of complement and local invasion of pro-inflammatory cells in a human patient with osteoarthritis (Dragomir et al. 2012). The immunogenicity of hyaluronan has been attributed to the presence of low-molecular weight fragments in this material, but it seems to be related rather to the presence of contaminating DNA in hyaluronan preparation (Filion and Phillips 2001). Paradoxically, alginate, which is often used for encapsulation and immunoprotection of cells, can also evoke an immune reaction. This is mainly due to impurities in this material, e.g. contamination with mitogens and endotoxins (Zimmermann et al. 1992, Breger et al. 2009). Other factors inducing immunogenicity of polysaccharides can be the agents used for their crosslinking, particularly glutaraldehyde (Lai 2012).

Nevertheless, in other polysaccharides, such as chitosan (VandeVord et al. 2002), gellan gum (SilvaCorreia et al. 2013), bacterial cellulose (Helenius et al. 2006, Mendes et al. 2009, Esguerra et al. 2010) and dextran (Ferreira et al. 2005), the immunogenicity was classified as mild. Adding pullulan to dextran increased its immunogenic activity (Abed et al. 2011). The immune response to biodegradable starch-based materials was even slighter than the reaction to other currently used synthetic and natural polymeric materials (Marques et al. 2005). Similarly, titanium coated with heparin/fibronectin complex revealed a weaker inflammatory response than pristine $\mathrm{Ti}$ (Li et al. 2011).

\section{Cellulose in vascular tissue engineering}

The specialized part of this review is focused on the potential use of cellulose in blood vessel reconstruction. One of the first attempts at vascular tissue engineering was carried out with microfibers made of regenerated cellulose, i.e. purified plant cellulose chemically converted from short fibers (coming e.g. from trees) into long fibers used in textiles and nonwovens. These fibers were applied for constructing threedimensional vascularized tissue in vitro. They were immobilized with fibronectin in order to improve cell adhesion, and were seeded with bovine coronary artery SMC. These cells proliferated on the scaffolds and, after they formed multilayers on the fibers, the fibers were removed by enzymatic digestion using cellulase. The remaining SMC aggregates maintained lumens after this procedure, and thus mimicked newly-formed blood vessels (Ko and Iwata 2001). Further experiments were performed on three-dimensional nanofibrous scaffolds with micropores made of bacterial cellulose. These scaffolds allowed the attachment and proliferation of human saphenous vein SMC on the surface and also in the inside of the scaffolds (Backdahl et al. 2008). In addition, the mechanical properties of nanofibrous bacterial cellulose scaffolds, evaluated by the shape of the stress-strain response, were reminiscent of the properties of the carotid artery, most probably due to the similarity in architecture of the nanofibril network (Backdahl et al. 2006).

Cellulose-based scaffolds were attractive not only for vascular SMC, but also for vascular endothelial cells. The adhesion, spreading, formation of an actin cytoskeleton, proliferation, metabolic activity and maturation of human saphenous vein cells was supported by nanofibrous bacterial cellulose scaffolds, particularly scaffolds functionalized with xyloglugan bearing RGDcontaining oligopeptides, i.e. ligands for integrin adhesion receptors on cells (Bodin et al. 2007, Fink et al. 2011). Similarly, the population densities of endothelial cells and the spontaneous formation of capillary tube-like structures in vitro were improved on nano- and microfibrous cellulose acetate scaffolds after they were combined with chitosan (Rubenstein et al. 2007). The angiogenic response to cellulose was also observed under in vivo conditions, i.e. after implantation of bacterial cellulose scaffolds in the form of a dorsal skinfold chamber into Syrian golden hamsters (Esguerra et al. 2010). 
Cellulose has also been used for creating tubular structures designed for replacing small-caliber vessels. The construction of functional small-caliber vascular replacements is relatively complicated, because these grafts are associated with the highest risk of restenosis and failure. Optimal prevention of restenosis is achieved by covering the inner surface of these grafts with endothelial cells. Wippermann et al. (2009) created hollow-shaped segments of bacterial cellulose $10 \mathrm{~mm}$ in length, 3.0-3.7 $\mathrm{mm}$ in inner diameter, and 0.6-1.0 $\mathrm{mm}$ in wall thickness. These grafts were used to replace the carotid arteries of eight pigs. After a follow-up period of 3 months, seven grafts $(87.5 \%)$ remained patent, whereas one graft was found to be occluded. All patent grafts developed not only a single inner layer of endothelium with a basement membrane and a thin layer of collagen, but also a concentric medial layer containing SMC and cellulose, and an outer layer of fibrous cells.

Similarly, bacterial cellulose grafts $4 \mathrm{~cm}$ in length and $4 \mathrm{~mm}$ in internal diameter were implanted bilaterally in the carotid arteries of eight sheep. Although $50 \%$ of the grafts occluded within two weeks, all patent grafts developed a confluent inner layer of endotheliallike cells (Malm et al. 2012). In addition, the mechanical properties of tubular structures created from bacterial cellulose seemed to be advantageous for vascular tissue engineering. For example, these structures exhibited a compliance response similar to that of human saphenous vein, and even higher than in vascular grafts made of expanded polytetrafluoroethylene (ePTFE) and polyethylene terephthalate (PET; Dacron), i.e. in prostheses currently used in clinical practice. In addition, the surface of bacterial cellulose was less thrombogenic when compared with ePTFE and Dacron (Zahedmanesh et al. 2011).

In spite of all these encouraging findings, cellulose is not an ideal scaffold for tissue engineering, due to its low degradation ability. As mentioned above, ideal scaffolds used in advanced tissue engineering should be constructed from resorbable materials that degrade proportionally to the tissue regeneration and are gradually replaced by a newly-formed functional tissue (Collins and Birkinshaw 2013). However, cellulose in the human organism behaves as a non-degradable or very slowly degradable material. For example, the degradation time of viscose cellulose sponges implanted subcutaneously into rats was longer than 60 weeks (Märtson et al. 1999). This very slow degradability of cellulose is due to the absence of enzymes that attack the $\beta(1 \rightarrow 4)$ linkage. These enzymes are present in microbial and fungal cells (for a review, see Märtson et al. 1999). In our experiments, we have therefore focused on inducing and controlling the cellulose degradability. An efficient method for inducing degradability of cellulose is oxidation. Oxidized cellulose can be generated by various techniques and by various oxidizing agents, such as the $\mathrm{HNO}_{3} / \mathrm{H}_{3} \mathrm{PO}_{4}-\mathrm{NANO}_{2}$ system, $\mathrm{CCl}_{4}$, periodate or 2,2,6,6-tetramethylpiperidinyl-1-oxyl radical (TEMPO) combined with $\mathrm{NaClO}$ (Roychowdhury and Kumar 2006, Saito et al. 2009, for a review, see Novotná et al. 2013). Oxidized cellulose is degradable by hydrolysis, mediated by hydrolytic enzymes present in the serum supplement of cell culture media in vitro and in macrophages in vivo (Dimitrijevich et al. 1990a,b).

Cellulose oxidation induces conversion of the glucose residues to glucuronic acid residues containing $-\mathrm{COOH}$ groups. The concentration of these groups modulates not only the degradation time of cellulose, but also its $\mathrm{pH}$, its swelling in a water environment, its mechanical stability, its drug loading efficiency, and other behavior of the material (Zhu et al. 2011). In addition, the $-\mathrm{COOH}$ groups, which are polar and negatively charged, can be used for functionalizing the oxidized cellulose with various biomolecules (Zimnitsky et al. 2005, 2006).

Oxidized cellulose has been widely used as a hemostatic and wound healing material. It is highly absorbable, able to initiate or accelerate blood coagulation, and displays antibacterial and antiviral effects. It is also a promising carrier for controlled drug delivery (for a review, see Novotná et al. 2013). Oxidized dialdehyde cellulose (DAC) has been applied as a biodegradable scaffold for tissue engineering. Microporous DAC membranes supported adhesion, proliferation and ECM formation in human neonatal skin fibroblast cells (Roychowdhury and Kumar 2006), and also proved to be suitable for engineering vocal fold lamina propria (Roychowdhury et al. 2009).

Our experiments were performed on cellulosebased materials modified by oxidation and/or functionalization with biomolecules. We have prepared fibrous scaffolds made of non-oxidized viscose, dialdehyde cellulose and 6-carboxycellulose with 2.1 wt. $\%$ or 6.6 wt. $\%$ of $-\mathrm{COOH}$ groups. In addition, all these material types were functionalized with arginine, i.e. an amino acid with a basic side chain, or with chitosan, in order to balance the relatively acid character of oxidized cellulose molecules. Two groups of samples, 
with and without functionalization, were then seeded with SMC derived from rat thoracic aorta by an explantation method (Novotná et al. 2009, 2013).

We found that oxidized cellulose with $2.1 \mathrm{wt}$ \% of $-\mathrm{COOH}$ groups was the most appropriate of all the tested materials for colonization with SMC. The cells on this material achieved an elongated shape, while they were rather spherical in shape on the other materials (Fig. 1). In addition, the number of cells found one week after seeding and the concentration of contractile proteins alpha-actin and SM1 and SM2 myosins, measured per mg of protein, were significantly higher on oxidized cellulose with 2.1 wt. \% of $-\mathrm{COOH}$ groups. Functionalization of the material with arginine and chitosan further improved the phenotypic maturation of SMC, which was manifested by a further increase in the concentration of alpha-actin and SM1 and SM2 myosins in these cells. Chitosan also improved the adhesion and growth of SMC. However, in comparison with the control polystyrene dishes, the proliferation activity of the cells on our cellulose-based materials was relatively low. This suggests that these materials can be used in applications where high proliferation activity of cells is not desirable, e.g. proliferation of SMC on vascular prostheses, which can lead to restenosis of the graft.
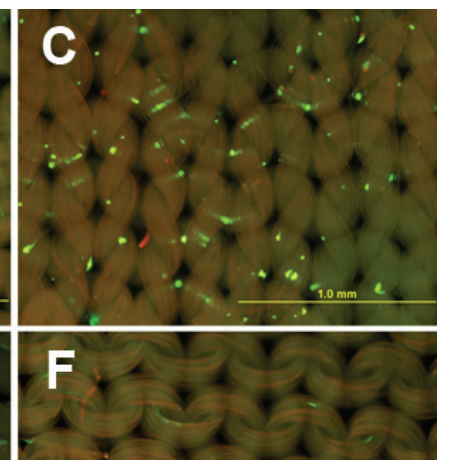

Fig. 1. Morphology and viability of vascular smooth muscle cells on day 7 after seeding on the following cellulose-based materials: viscose (A, B, C); oxidized cellulose with 2.1 wt. $\%$ of $-\mathrm{COOH}$ groups (D, E, F); oxidized cellulose with 6.6 wt. $\%$ of $-\mathrm{COOH}$ groups $(\mathbf{G}, \quad \mathbf{H}, \mathbf{I}) ; \quad$ dialdehyde cellulose (J, K). A, D, G, J: materials with no modification; $\mathbf{B}, \mathbf{E}, \mathbf{H}, \mathbf{K}$ : materials functionalized with chitosan; C, F, I: materials functionalized with arginine. LIVE/DEAD staining, obj. 4x. Olympus IX 51 microscope, DP 70 digital camera, obj. $4 x$, bar $=1 \mathrm{~mm}$.
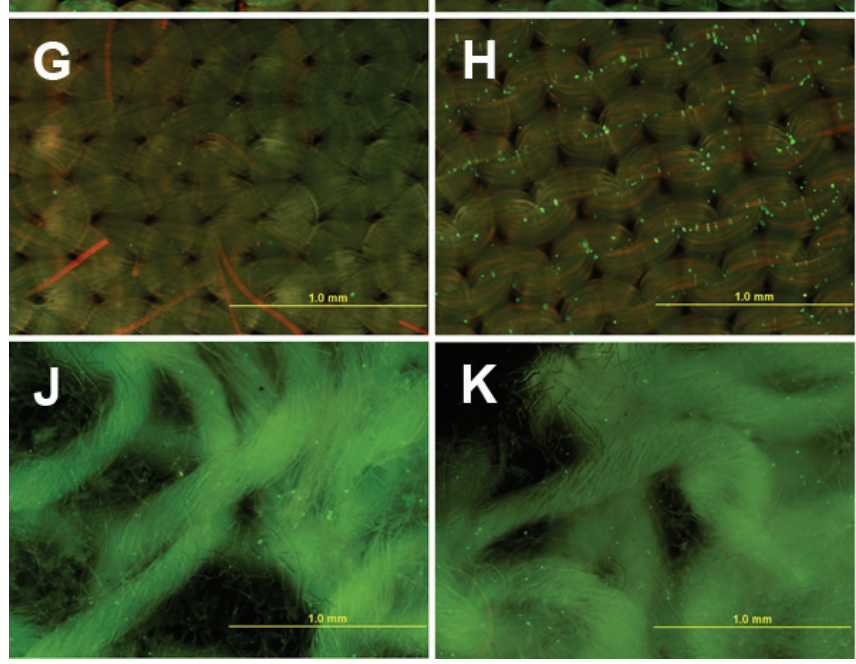

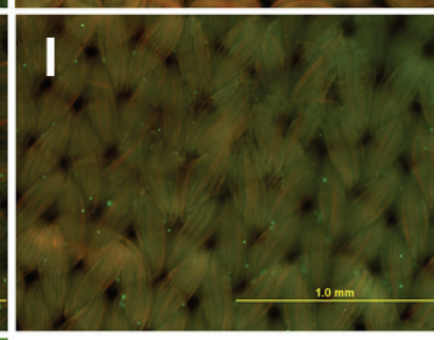

On the other hand, 6-carboxycellulose with 2.1 wt. $\%$ of $-\mathrm{COOH}$ groups, particularly if functionalized with arginine or chitosan, provided better support for SMC growth than corresponding groups of 6-carboxycellulose with 6.6 wt. \% of $-\mathrm{COOH}$ groups, viscose and dialdehyde cellulose. In the case of 6-carboxycellulose with 6.6 wt. $\%$ of $-\mathrm{COOH}$, this was probably due to the relatively high acidity of this material, and also due to its lower stability in the cell culture environment and during manipulation. In other words, the content of $6.6 \mathrm{wt}$. \% - $\mathrm{COOH}$ groups appeared to be too high for this material to be biocompatible and stable. In addition, the stability of dialdehyde cellulose proved to be very low, probably because of a specific 
arrangement of the fibers in its fabric, which resembled a loose network, while in oxidized cellulose or viscose the fibers were densely packed in thick rope-like bundles (Fig. 1). The highest stability was observed in viscose materials, which had almost no tendency to degrade. The stability of oxidized cellulose with 2.1 wt. \% of $-\mathrm{COOH}$ was sufficiently high, as it did not disintegrate while the samples were being handled, and its degradation in the cell culture system was relatively slow in comparison with oxycellulose with 6.6 wt. \% of $-\mathrm{COOH}$ and dialdehyde cellulose (Novotná et al. 2009, 2013).

Similar results were obtained in our earlier study performed on polyethylene (PE) foils doped with various concentrations (0-20 wt. \%) of calcium salt of oxidized cellulose (OKCEL Ca-L, Synthesia, Pardubice, Czech Republic). The surface of the samples was polished in order to enhance the exposure of oxidized cellulose to the cells. The samples were seeded with SMC derived from rat aorta. On all samples doped with oxidized cellulose, the cells proliferated better than on non-doped PE, but the highest cell numbers were found on samples with lower concentrations of oxidized cellulose, i.e. 1-5 wt. \% (Mikulíková et al. 2005).

\section{Conclusions}

Polysaccharides have proved to be very important biological polymers indispensable in advanced tissue engineering, cell therapies and regenerative medicine. They are equally important as widely-used synthetic degradable and non-degradable polymers, such as polylactides, polyglycolides, polycaprolacton, PTFE and PET, though they often seem to be overshadowed by these polymers. In the form of injectable hydrogels, polysaccharides, particularly alginate and hyaluronan, are essential for encapsulation and delivery of cells directly to the organism (pancreatic islets, ovarian follicles) or to three-dimensional scaffolds for tissue engineering. Polysaccharides can also be prepared in the form of porous or fibrous scaffolds, the latter often being created by an advanced electrospinning technique. Polysaccharides are also important biomolecules for further modification of various polymeric and other materials designed for tissue replacement, in order to increase their bioactivity, e.g. cell retention. For specific purposes, such as engineering of hard or conductive tissues, polysaccharides can also be combined with ceramic, carbon and metallic nanoparticles. Polysaccharides are also important carriers for the delivery of growth factors and drugs to cells. Thus, polysaccharides are promising materials for further development and for broader applications in clinical practice.

\section{Conflict of Interest}

There is no conflict of interest.

\section{Acknowledgements}

This study was supported by the Grant Agency of the Czech Republic (grants No. P108/12/1168 and P108/11/1857) and by the Ministry of Health of the Czech Republic (grant No. NT13297-4/2012). Mr. Robin Healey (Czech Technical University in Prague) is gratefully acknowledged for his language revision of the manuscript.

\section{References}

ABED A, ASSOUL N, BA M, DERKAOUI SM, PORTES P, LOUEDEC L, FLAUD P, BATAILLE I, LETOURNEUR D, MEDDAHI-PELLÉ A: Influence of polysaccharide composition on the biocompatibility of pullulan/dextran-based hydrogels. J Biomed Mater Res A 96: 535-542, 2011.

AL-HAJRY HA, AL-MASKRY SA, AL-KHAROUSI LM, EL-MARDI O, SHAYYA WH, GOOSEN MF: Electrostatic encapsulation and growth of plant cell cultures in alginate. Biotechnol Prog 15: 768-774, 1999.

ANDERSSON J, STENHAMRE H, BÄCKDAHL H, GATENHOLM P: Behavior of human chondrocytes in engineered porous bacterial cellulose scaffolds. J Biomed Mater Res A 94: 1124-1132, 2010.

BACKDAHL H, ESGUERRA M, DELBRO D, RISBERG B, GATENHOLM P: Engineering microporosity in bacterial cellulose scaffolds. J Tissue Eng Regen Med 2: 320-330, 2008.

BACKDAHL H, HELENIUS G, BODIN A, NANNMARK U, JOHANSSON BR, RISBERG B, GATENHOLM P: Mechanical properties of bacterial cellulose and interactions with smooth muscle cells. Biomaterials 27: 2141$2149,2006$. 
BALDWIN AD, KIICK KL: Polysaccharide-modified synthetic polymeric biomaterials. Biopolymers 94: 128-140, 2010.

BANERJEE A, ARHA M, CHOUDHARY S, ASHTON RS, BHATIA SR, SCHAFFER DV, KANEA RS: The influence of hydrogel modulus on the proliferation and differentiation of encapsulated neural stem cells. Biomaterials 30: 4695-4699, 2009.

BAO J, SHI Y, SUN H, YIN X, YANG R, LI L, CHEN X, BU H: Construction of a portal implantable functional tissue-engineered liver using perfusion-decellularized matrix and hepatocytes in rats. Cell Transplant 20: 753-766, 2011.

BAO L, YANG W, MAO X, MOU S, TANG S: Agar/collagen membrane as skin dressing for wounds. Biomed Mater 3: $044108,2008$.

BELLAMKONDA R, RANIERI JP, BOUCHE N, AEBISCHER P: Hydrogel-based three-dimensional matrix for neural cells. J Biomed Mater Res 29: 663-671, 1995.

BERLANGA-REYES CM, CARVAJAL-MILLÁN E, LIZARDI-MENDOZA J, RASCÓN-CHU A, MARQUEZESCALANTE JA, MARTÍNEZ-LÓPEZ AL: Maize arabinoxylan gels as protein delivery matrices. Molecules 14: 1475-1482, 2009.

BHATTACHARYA M, MALINEN MM, LAUREN P, LOU YR, KUISMA SW, KANNINEN L, LILLE M, CORLU A, GUGUEN-GUILLOUZO C, IKKALA O, LAUKKANEN A, URTTI A, YLIPERTTULA M: Nanofibrillar cellulose hydrogel promotes three-dimensional liver cell culture. J Control Release 164: 291-298, 2012.

BODIN A, AHRENSTEDT L, FINK H, BRUMER H, RISBERG B, GATENHOLM P: Modification of nanocellulose with a xyloglucan-RGD conjugate enhances adhesion and proliferation of endothelial cells: implications for tissue engineering. Biomacromolecules 8: 3697-3704, 2007.

BODIN A, BHARADWAJ S, WU S, GATENHOLM P, ATALA A, ZHANG Y: Tissue-engineered conduit using urine-derived stem cells seeded bacterial cellulose polymer in urinary reconstruction and diversion. Biomaterials 31: 8889-8901, 2010.

BREGER JC, LYLE DB, SHALLCROSS JC, LANGONE JJ, WANG NS: Defining critical inflammatory parameters for endotoxin impurity in manufactured alginate microcapsules. J Biomed Mater Res B Appl Biomater 91: 755-765, 2009.

CHEN JP, TSAI MJ, LIAO HT: Incorporation of biphasic calcium phosphate microparticles in injectable thermoresponsive hydrogel modulates bone cell proliferation and differentiation. Colloids Surf B Biointerfaces 110: 120-129, 2013.

CHOI JS, YOO HS: Chitosan/pluronic hydrogel containing bFGF/heparin for encapsulation of human dermal fibroblasts. J Biomater Sci Polym Ed 24: 210-223, 2013.

CHOO JQ, LAU DP, CHUI CK, YANG T, CHNG CB, TEOH SH: Design of a mechanical larynx with agarose as a soft tissue substitute for vocal fold applications. J Biomech Eng 132: 065001, 2010.

COIMBRA P, FERREIRA P, DE SOUSA HC, BATISTA P, RODRIGUES MA, CORREIA IJ, GIL MH: Preparation and chemical and biological characterization of a pectin/chitosan polyelectrolyte complex scaffold for possible bone tissue engineering applications. Int J Biol Macromol 48: 112-118, 2011.

COLLINS MN, BIRKINSHAW C: Hyaluronic acid based scaffolds for tissue engineering - a review. Carbohydr Polym 92: 1262-1279, 2013.

DAHLMANN J, KRAUSE A, MÖLLER L, KENSAH G, MÖWES M, DIEKMANN A, MARTIN U, KIRSCHNING A, GRUH I, DRÄGER G: Fully defined in situ cross-linkable alginate and hyaluronic acid hydrogels for myocardial tissue engineering. Biomaterials 34: 940-951, 2013.

DENG C, VULESEVIC B, ELLIS C, KORBUTT GS, SUURONEN EJ: Vascularization of collagen-chitosan scaffolds with circulating progenitor cells as potential site for islet transplantation. $J$ Control Release 152: e196-e198, 2011.

DENG Y, SUN Y, CHEN X, ZHU P, WEI S: Biomimetic synthesis and biocompatibility evaluation of carbonated apatites template-mediated by heparin. Mater Sci Eng C Mater Biol Appl 33: 2905-2913, 2013. 
DESIDERIO V, DE FRANCESCO F, SCHIRALDI C, DE ROSA A, LA GATTA A, PAINO F, D'AQUINO R, FERRARO GA, TIRINO V, PAPACCIO G: Human Ng2+ adipose stem cells loaded in vivo on a new crosslinked hyaluronic acid-Lys scaffold fabricate a skeletal muscle tissue. J Cell Physiol 228: 1762-1773, 2013.

DIMITRIJEVICH SD, TATARKO M, GRACY RW, LINSKY CB, OLSEN C: Biodegradation of oxidized regenerated celulose. Carbohydr Res 195: 247-256, 1990a.

DIMITRIJEVICH SD, TATARKO M, GRACY RW, WISE GE, OAKFORD LX, LINSKY CB, KAMP L: In vivo degradation of oxidized, regenerated cellulose. Carbohydr Res 198: 331-341, 1990b.

DISCHER DE, JANMEY P, WANG YL: Tissue cells feel and respond to the stiffness of their substrate. Science 310: 1139-1143, 2005.

DOUGLAS T, WLODARCZYK M, PAMULA E, DECLERCQ H, DE MULDER E, BUCKO M, BALCAEN L, VANHAECKE F, CORNELISSEN R, DUBRUEL P, JANSEN J, LEEUWENBURGH S: Enzymatic mineralization of gellan gum hydrogel for bone tissue-engineering applications and its enhancement by polydopamine. J Tissue Eng Regen Med DOI: 10.1002/term.1616, 2012 (in press).

DRAGOMIR CL, SCOTT JL, PERINO G, ADLER R, FEALY S, GOLDRING MB: Acute inflammation with induction of anaphylatoxin C5a and terminal complement complex C5b-9 associated with multiple intraarticular injections of hylan G-F 20: a case report. Osteoarthritis Cartilage 20: 791-795, 2012.

DREWA T, ADAMOWICZ J, LYSIK J, POLACZEK J, PIELICHOWSKI J: Chitosan scaffold enhances nerve regeneration within the in vitro reconstructed bladder wall: an animal study. Urol Int 81: 330-334, 2008.

DVIR T, TIMKO BP, BRIGHAM MD, NAIK SR, KARAJANAGI SS, LEVY O, JIN H, PARKER KK, LANGER R, KOHANE DS: Nanowired three dimensional cardiac patches. Nat Nanotechnol 6: 720-725, 2011.

DU F, WANG H, ZHAO W, LI D, KONG D, YANG J, ZHANG Y: Gradient nanofibrous chitosan/poly $\varepsilon$-caprolactone scaffolds as extracellular microenvironments for vascular tissue engineering. Biomaterials 33: 762-770, 2012.

DUAN B, HOCKADAY LA, KAPETANOVIC E, KANG KH, BUTCHER JT: Stiffness and adhesivity control aortic valve interstitial cell behavior within hyaluronic acid based hydrogels. Acta Biomater 9: 7640-7650, 2013.

DUGAN JM, COLLINS RF, GOUGH JE, EICHHORN SJ: Oriented surfaces of adsorbed cellulose nanowhiskers promote skeletal muscle myogenesis. Acta Biomater 9: 4707-4715, 2013.

DYONDI D, WEBSTER TJ, BANERJEE R: A nanoparticulate injectable hydrogel as a tissue engineering scaffold for multiple growth factor delivery for bone regeneration. Int J Nanomedicine 8: 47-59, 2013.

ENTCHEVA E, BIEN H, YIN L, CHUNG CY, FARRELL M, KOSTOV Y: Functional cardiac cell constructs on cellulose-based scaffolding. Biomaterials 25: 5753-5762, 2004.

ERICKSON IE, KESTLE SR, ZELLARS KH, DODGE GR, BURDICK JA, MAUCK RL: Improved cartilage repair via in vitro pre-maturation of MSC-seeded hyaluronic acid hydrogels. Biomed Mater 7: 024110, 2012.

ESGUERRA M, FINK H, LASCHKE MW, JEPPSSON A, DELBRO D, GATENHOLM P, MENGER MD, RISBERG B: Intravital fluorescent microscopic evaluation of bacterial cellulose as scaffold for vascular grafts. $J$ Biomed Mater Res A 93: 140-149, 2010.

FERREIRA L, GIL MH, CABRITA AM, DORDICK JS: Biocatalytic synthesis of highly ordered degradable dextranbased hydrogels. Biomaterials 26: 4707-4716, 2005.

FILION MC, PHILLIPS NC: Pro-inflammatory activity of contaminating DNA in hyaluronic acid preparations. J Pharm Pharmacol 53: 555-561, 2001.

FILIPPOV SK, SEDLÁČEK O, BOGOMOLOVA A, VĚTŘÍK M, JIRÁK D, KOVÁŘ J, KUČKA J, BALS S, TURNER S, ŠTĚPÁNEK P, HRUBÝ M: Glycogen as a biodegradable construction nanomaterial for in vivo use. Macromol Biosci 12: 1731-1738, 2012.

FILOVÁ E, JELÍNEK F, HANDL M, LYTVYNETS A, RAMPICHOVÁ M, VARGA F, ČINÁTL J, SOUKUP T, TRČ T, AMLER E: Novel composite hyaluronan/type I collagen/fibrin scaffold enhances repair of osteochondral defect in rabbit knee. J Biomed Mater Res B Appl Biomater 87: 415-424, 2008.

FINK H, AHRENSTEDT L, BODIN A, BRUMER H, GATENHOLM P, KRETTEK A, RISBERG B: Bacterial cellulose modified with xyloglucan bearing the adhesion peptide RGD promotes endothelial cell adhesion and metabolism - a promising modification for vascular grafts. J Tissue Eng Regen Med 5: 454-463, 2011. 
FRICAIN JC, SCHLAUBITZ S, LE VISAGE C, ARNAULT I, DERKAOUI SM, SIADOUS R, CATROS S, LALANDE C, BAREILLE R, RENARD M, FABRE T, CORNET S, DURAND M, LÉONARD A, SAHRAOUI N, LETOURNEUR D, AMÉDÉE J: A nano-hydroxyapatite-pullulan/dextran polysaccharide composite macroporous material for bone tissue engineering. Biomaterials 34: 2947-2959, 2013.

FROHBERGH ME, KATSMAN A, BOTTA GP, LAZAROVICI P, SCHAUER CL, WEGST UG, LELKES PI: Electrospun hydroxyapatite-containing chitosan nanofibers crosslinked with genipin for bone tissue engineering. Biomaterials 33: 9167-9178, 2012.

GALPERIN A, OLDINSKI RA, FLORCZYK SJ, BRYERS JD, ZHANG M, RATNER BD: Integrated bi-layered scaffold for osteochondral tissue engineering. Adv Health Mater 2: 872-883, 2013.

GAO J, LIU R, WU J, LIU Z, LI J, ZHOU J, HAO T, WANG Y, DU Z, DUAN C, WANG C: The use of chitosan based hydrogel for enhancing the therapeutic benefits of adipose-derived MSCs for acute kidney injury. Biomaterials 33: 3673-3681, 2012.

GARG HG, JOSEPH PA, THOMPSON BT, HALES CA, TOIDA T, IMANARI T, CAPILA I, LINHARDT RJ: Effect of fully sulfated glycosaminoglycans on pulmonary artery smooth muscle cell proliferation. Arch Biochem Biophys 371: 228-233, 1999.

GLUKHOVA MA, KOTELIANSKY VE: Integrins, cytoskeletal and extracellular matrix proteins in developing smooth muscle cells of human aorta. In: The Vascular Smooth Muscle Cell. Molecular and Biological Response to the Extracelular Matrix. SCHWARTZ SM, MECHAM RP (eds), Academic Press, San Diego, London, 1995, pp 37-79.

GOMES ME, AZEVEDO HS, MOREIRA AR, ELLÄ V, KELLOMÄKI M, REIS RL: Starch-poly(epsiloncaprolactone) and starch-poly(lactic acid) fibre-mesh scaffolds for bone tissue engineering applications: structure, mechanical properties and degradation behaviour. J Tissue Eng Regen Med 2: 243-252, 2008.

GONG Y, HE L, LI J, ZHOU Q, MA Z, GAO C, SHEN J: Hydrogel-filled polylactide porous scaffolds for cartilage tissue engineering. J Biomed Mater Res B Appl Biomater 82: 192-204, 2007.

GU H, YUE Z, LEONG WS, NUGRAHA B, TAN LP: Control of in vitro neural differentiation of mesenchymal stem cells in 3D macroporous, cellulosic hydrogels. Regen Med 5: 245-253, 2010.

HAJIALI H, SHAHGASEMPOUR S, NAIMI-JAMAL MR, PETROVI H: Electrospun PGA/gelatin nanofibrous scaffolds and their potential application in vascular tissue engineering. Int J Nanomedicine 6: 2133-2141, 2011.

HAN D, GOUMA PI: Electrospun bioscaffolds that mimic the topology of extracellular matrix. Nanomedicine 2: 37-41, 2006.

HATCH A, HANSMANN G, MURTHY SK: Engineered alginate hydrogels for effective microfluidic capture and release of endothelial progenitor cells from whole blood. Langmuir 27: 4257-4264, 2011.

HERNÁNDEZ-ESPINOZA AB, PIÑÓN-MUÑIZ MI, RASCÓN-CHU A, SANTANA-RODRÍGUEZ VM, CARVAJAL-MILLAN E: Lycopene/arabinoxylan gels: rheological and controlled release characteristics. Molecules 17: 2428-2436, 2012.

HOCKADAY LA, KANG KH, COLANGELO NW, CHEUNG PY, DUAN B, MALONE E, WU J, GIRARDI LN, BONASSAR LJ, LIPSON H, CHU CC, BUTCHER JT: Rapid 3D printing of anatomically accurate and mechanically heterogeneous aortic valve hydrogel scaffolds. Biofabrication 4: 035005, 2012.

HONG H, DONG N, SHI J, CHEN S, GUO C, HU P, QI H: Fabrication of a novel hybrid heart valve leaflet for tissue engineering: an in vitro study. Artif Organs 33: 554-558, 2009.

HONG HJ, LEE JS, CHOI JW, MIN BH, LEE HB, KIM CH: Transplantation of autologous chondrocytes seeded on a fibrin/hyaluronan composite gel into tracheal cartilage defects in rabbits: preliminary results. Artif Organs 36: 998-1006, 2012.

HROMÁDKOVÁ Z, PAULSEN BS, POLOVKA M, KOŠŤÁLOVÁ Z, EBRINGEROVÁ A: Structural features of two heteroxylan polysaccharide fractions from wheat bran with anti-complementary and antioxidant activities. Carbohydr Polym 93: 22-30, 2013.

HU N, WU H, XUE C, GONG Y, WU J, XIAO Z, YANG Y, DING F, GU X: Long-term outcome of the repair of $50 \mathrm{~mm}$ long median nerve defects in rhesus monkeys with marrow mesenchymal stem cells-containing, chitosan-based tissue engineered nerve grafts. Biomaterials 34: 100-111, 2013. 
HUSSAIN A, COLLINS G, YIP D, CHO CH: Functional 3-D cardiac co-culture model using bioactive chitosan nanofiber scaffolds. Biotechnol Bioeng 110: 637-647, 2013.

INOUE Y, HASEGAWA S, YAMADA T, DATE Y, MIZUTANI H, NAKATA S, AKAMATSU H: Lignin induces ES cells to differentiate into neuroectodermal cells through mediation of the Wnt signaling pathway. PLoS One 8: e66376, 2013.

ISHIBASHI K, MATSUDA T: Reconstruction of a hybrid vascular graft hierarchically layered with three cell types. ASAIO J 40: M284-M290, 1994.

JEONG SI, JEON O, KREBS MD, HILL MC, ALSBERG E: Biodegradable photo-crosslinked alginate nanofibre scaffolds with tuneable physical properties, cell adhesivity and growth factor release. Eur Cell Mater 24: 331-343, 2012.

JOHNSON AS, O'SULLIVAN E, D'AOUST LN, OMER A, BONNER-WEIR S, FISHER RJ, WEIR GC, COLTON CK: Quantitative assessment of islets of langerhans encapsulated in alginate. Tissue Eng Part C Methods 17: 435-449, 2011.

KHANARIAN NT, JIANG J, WAN LQ, MOW VC, LU HH: A hydrogel-mineral composite scaffold for osteochondral interface tissue engineering. Tissue Eng Part A 18: 533-545, 2012.

KHANG G, LEE S, KIM H, SILVA-CORREIA J, GOMES M, VIEGAS C, DIAS I, OLIVEIRA J, REIS R: Biological evaluation of intervertebral disc cells in different formulations of gellan gum-based hydrogels. J Tissue Eng Regen Med DOI: 10.1002/term.1625, 2012 (in press).

KIM IL, KHETAN S, BAKER BM, CHEN CS, BURDICK JA: Fibrous hyaluronic acid hydrogels that direct MSC chondrogenesis through mechanical and adhesive cues. Biomaterials 34: 5571-5580, 2013.

KIM M, HONG B, LEE J, KIM SE, KANG SS, KIM YH, TAE G: Composite system of PLCL scaffold and heparinbased hydrogel for regeneration of partial-thickness cartilage defects. Biomacromolecules 13: 2287-2298, 2012.

KINGKAEW J, JATUPAIBOON N, SANCHAVANAKIT N, PAVASANT P, PHISALAPHONG M: Biocompatibility and growth of human keratinocytes and fibroblasts on biosynthesized cellulose-chitosan film. J Biomater Sci Polym Ed 21: 1009-1021, 2010.

KO IK, IWATA H: An approach to constructing three-dimensional tissue. Ann NY Acad Sci 944: 443-455, 2001.

KOKKONEN HE, ILVESARO JM, MORRA M, SCHOLS HA, TUUKKANEN J: Effect of modified pectin molecules on the growth of bone cells. Biomacromolecules 8: 509-515, 2007.

KOKKONEN H, CASSINELLI C, VERHOEF R, MORRA M, SCHOLS HA, TUUKKANEN J: Differentiation of osteoblasts on pectin-coated titanium. Biomacromolecules 9: 2369-2376, 2008.

KOKKONEN H, VERHOEF R, KAUPPINEN K, MUHONEN V, JØRGENSEN B, DAMAGER I, SCHOLS HA, MORRA M, ULVSKOV P, TUUKKANEN J: Affecting osteoblastic responses with in vivo engineered potato pectin fragments. J Biomed Mater Res A 100: 111-119, 2012.

KONG L, ZIEGLER GR: Role of molecular entanglements in starch fiber formation by electrospinning. Biomacromolecules 13: 2247-2253, 2012.

KORKMAZ M, YAKUT T, NARCI A, GÜVENÇ BH, GÜILTEN T, YAĞMURCA M, YIĞIT B, BILIR A: Esophageal muscle cell interaction with biopolymers. Med Sci Monit 13: BR46-BR49, 2007.

KOTHAPALLI D, FLOWERS J, XU T, PURÉ E, ASSOIAN RK: Differential activation of ERK and Rac mediates the proliferative and anti-proliferative effects of hyaluronan and CD44. J Biol Chem 283: 31823-31829, 2008.

KOWALSKA-LUDWICKA K, CALA J, GROBELSKI B, SYGUT D, JESIONEK-KUPNICKA D, KOLODZIEJCZYK M, BIELECKI S, PASIEKA Z: Modified bacterial cellulose tubes for regeneration of damaged peripheral nerves. Arch Med Sci 9: 527-534, 2013.

KUMAR PT, RAMYA C, JAYAKUMAR R, NAIR SK, LAKSHMANAN VK: Drug delivery and tissue engineering applications of biocompatible pectin-chitin/nano $\mathrm{CaCO} 3$ composite scaffolds. Colloids Surf B Biointerfaces 106: 109-116, 2013.

KUMMER MP, ABBOTT JJ, DINSER S, NELSON BJ: Artificial vitreous humor for in vitro experiments. Conf Proc IEEE Eng Med Biol Soc 2007: 6407-6410, 2007.

KUO YC, WANG CT: Neuronal differentiation of induced pluripotent stem cells in hybrid polyester scaffolds with heparinized surface. Colloids Surf B Biointerfaces 100: 9-15, 2012. 
LAI JY: Biocompatibility of genipin and glutaraldehyde cross-linked chitosan materials in the anterior chamber of the eye. Int J Mol Sci 13: 10970-10985, 2012.

LANGER R, VACANTI JP: Tissue engineering. Science 260: 920-926, 1993.

LAVERGNE M, DERKAOUI M, DELMAU C, LETOURNEUR D, UZAN G, LE VISAGE C: Porous polysaccharidebased scaffolds for human endothelial progenitor cells. Macromol Biosci 12: 901-910, 2012.

LEE KY, JEONG L, KANG YO, LEE SJ, PARK WH: Electrospinning of polysaccharides for regenerative medicine. Adv Drug Deliv Rev 61: 1020-1032, 2009.

LI G, YANG P, GUO X, HUANG N, SHEN R: An in vitro evaluation of inflammation response of titanium functionalized with heparin/fibronectin complex. Cytokine 56: 208-217, 2011.

LIN HY, CHEN HH, CHANG SH, NI TS: Pectin-chitosan-PVA nanofibrous scaffold made by electrospinning and its potential use as a skin tissue scaffold. J Biomater Sci Polym Ed 24: 470-484, 2013.

LIU J, XU HHK, ZHOU H, WEIR MD, CHEN Q, TROTMAN CA: Human umbilical cord stem cell encapsulation in novel macroporous and injectable fibrin for muscle tissue engineering. Acta Biomater 9: 4688-4697, 2013.

LIU L, WON YJ, COOKE PH, COFFIN DR, FISHMAN ML, HICKS KB, MA PX: Pectin/poly(lactide-co-glycolide) composite matrices for biomedical applications. Biomaterials 25: 3201-3210, 2004.

LORD MS, YU W, CHENG B, SIMMONS A, POOLE-WARREN L, WHITELOCK JM: The modulation of platelet and endothelial cell adhesion to vascular graft materials by perlecan. Biomaterials 30: 4898-4906, 2009.

MALM CJ, RISBERG B, BODIN A, BÄCKDAHL H, JOHANSSON BR, GATENHOLM P, JEPPSSON A: Small calibre biosynthetic bacterial cellulose blood vessels: 13-months patency in a sheep model. Scand Cardiovasc $J$ 46: 57-62, 2012.

MAREKOVÁ D, LESNÝ P, JENDELOVÁ P, MICHÁLEK J, KOSTECKÁ P, PŘÁDNÝ M, MARTINOVÁ L, PANTOFLÍČEK T, RYSKA M, SYKOVÁ E: Hepatocyte growth on polycapronolactone and 2-hydroxyethylmethacrylate nanofiber sheets enhanced by bone marrow-derived mesenchymal stromal cells. Hepatogastroenterology 60: 1156-1163, 2013.

MARQUES AP, REIS RL, HUNT JA: An in vivo study of the host response to starch-based polymers and composites subcutaneously implanted in rats. Macromol Biosci 5: 775-785, 2005.

MCHUGH DJ (ed): Production and utilization of products from commercial seaweeds. FAO Fish Tech Pap 288, 1987, pp 198.

MENDES AC, BARAN ET, PEREIRA RC, AZEVEDO HS, REIS RL: Encapsulation and survival of a chondrocyte cell line within xanthan gum derivative. Macromol Biosci 12: 350-359, 2012.

MENDES PN, RAHAL SC, PEREIRA-JUNIOR OC, FABRIS VE, LENHARO SL, DE LIMA-NETO JF, DA CRUZ LANDIM-ALVARENGA F: In vivo and in vitro evaluation of an Acetobacter xylinum synthesized microbial cellulose membrane intended for guided tissue repair. Acta Vet Scand 51: 12, 2009.

MENG S, ROUABHIA M, ZHANG Z: Electrical stimulation modulates osteoblast proliferation and bone protein production through heparin-bioactivated conductive scaffolds. Bioelectromagnetics 34: 189-199, 2013.

MIKULÍKOVÁ R, KOLÁŘOVÁ K, BAČÁKOVÁ L, ŠVORČÍK V: Biocompatibility of polyethylene doped with oxycellulose. Mater Sci Forum 482: 251-254, 2005.

MINEO A, SUZUKI R, KUROYANAGI Y: Development of an artificial dermis composed of hyaluronic acid and collagen. J Biomater Sci Polym Ed 24: 726-740, 2013.

MOHAMMADI H: Nanocomposite biomaterial mimicking aortic heart valve leaflet mechanical behaviour. Proc Inst Mech Eng H 225: 718-722, 2011.

MOTHE AJ, TAM RY, ZAHIR T, TATOR CH, SHOICHET MS: Repair of the injured spinal cord by transplantation of neural stem cells in a hyaluronan-based hydrogel. Biomaterials 34: 3775-3783, 2013.

MUNARIN F, GUERREIRO SG, GRELLIER MA, TANZI MC, BARBOSA MA, PETRINI P, GRANJA PL: Pectinbased injectable biomaterials for bone tissue engineering. Biomacromolecules 12: 568-577, 2011.

MUNARIN F, TANZI MC, PETRINI P: Advances in biomedical applications of pectin gels. Int J Biol Macromol 51: 681-689, 2012.

NAKAYAMA Y, TSUJINAKA T: Acceleration of robust "biotube" vascular graft fabrication by in-body tissue architecture technology using a novel eosin Y-releasing mold. J Biomed Mater Res B Appl Biomater 102: 231-238, 2014. 
NOVOTNÁ K, BAČÁKOVÁ L, LISÁ V, HAVELKA P, SOPUCH T, KLEPETÁŘ J: Vascular smooth muscle cells in cultures on biofunctionalized cellulose-based scaffolds. Eng Biomater 12: 21-24, 2009.

NOVOTNÁ K, HAVELKA P, SOPUCH T, KOLÁŘOVÁ K, VOSMANSKÁ V, LISÁ V, ŠVORČÍK V, BAČÁKOVÁ L: Cellulose-based materials as scaffolds for tissue engineering. Cellulose 20: 2263-2278, 2013.

O'SULLIVAN AC: Cellulose: the structure slowly unravels. Cellulose 4: 173-207, 1997.

OLIVEIRA JT, CRAWFORD A, MUNDY JM, MOREIRA AR, GOMES ME, HATTON PV, REIS RL: A cartilage tissue engineering approach combining starch-polycaprolactone fibre mesh scaffolds with bovine articular chondrocytes. J Mater Sci Mater Med 18: 295-302, 2007.

OLIVEIRA JT, REIS RL: Polysaccharide-based materials for cartilage tissue engineering applications. $J$ Tissue Eng Regen Med 5: 421-436, 2011.

PARK SH, GIL ES, CHO H, MANDAL BB, TIEN LW, MIN BH, KAPLAN DL: Intervertebral disk tissue engineering using biphasic silk composite scaffolds. Tissue Eng Part A 18: 447-458, 2012.

PARK SJ, LI Z, HWANG IN, HUH KM, MIN KS: Glycol chitin-based thermoresponsive hydrogel scaffold supplemented with enamel matrix derivative promotes odontogenic differentiation of human dental pulp cells. J Endod 39: 1001-1007, 2013.

PAYEN A: Mémoire sur la composition du tissu propre des plantes et du ligneux (Memoir on the composition of the tissue of plants and of woody material). Comptes Rendus 7: 1052-1056, 1838.

PETERSEN N, GATENHOLM P: Bacterial cellulose-based materials and medical devices: current state and perspectives. Appl Microbiol Biotechnol 91: 1277-1286, 2011.

PITARRESI G, FIORICA C, PALUMBO FS, RIGOGLIUSO S, GHERSI G, GIAMMONA G: Heparin functionalized polyaspartamide/polyester scaffold for potential blood vessel regeneration. $J$ Biomed Mater Res A DOI: 10.1002/jbm.a.34818, 2013 (in press).

RAMASWAMY S, SCHORNACK PA, SMELKO AG, BORONYAK SM, IVANOVA J, MAYER JE JR, SACKS MS: Superparamagnetic iron oxide (SPIO) labeling efficiency and subsequent MRI tracking of native cell populations pertinent to pulmonary heart valve tissue engineering studies. NMR Biomed 25: 410-417, 2012.

RENANI HB, GHORBANI M, BENI BH, Z KARIMI Z, MIRHOSSEINI MM, ZARKESH H, KABIRI A: Determination and comparison of specifics of nucleus pulposus cells of human intervertebral disc in alginate and chitosan-gelatin scaffolds. Adv Biomed Res 1: 81, 2012.

RISBUD MV, BHARGAVA S, BHONDE RR: In vivo biocompatibility evaluation of cellulose macrocapsules for islet immunoisolation: Implications of low molecular weight cut-off. J Biomed Mater Res A 66: 86-92, 2003.

RIVAS S, CONDE E, MOURE A, DOMÍNGUEZ H, PARAJÓ JC: Characterization, refining and antioxidant activity of saccharides derived from hemicelluloses of wood and rice husks. Food Chem 141: 495-502, 2013.

RUBENSTEIN D, HAN D, GOLDGRABEN S, EL-GENDI H, GOUMA PI, FRAME MD: Bioassay chamber for angiogenesis with perfused explanted arteries and electrospun scaffolding. Microcirculation 14: 723-737, 2007.

SABAPATHY V, RAVI S, SRIVASTAVA V, SRIVASTAVA A, KUMAR S: Long-term cultured human term placenta-derived mesenchymal stem cells of maternal origin displays plasticity. Stem Cells Int 2012: 174328, 2012.

SAITO T, HIROTA M, TAMURA N, KIMURA S, FUKUZUMI H, HEUX L, ISOGAI A: Individualization of nanosized plant cellulose fibrils by direct surface carboxylation using TEMPO catalyst under neutral conditions. Biomacromolecules 10: 1992-1996, 2009.

SALACINSKI HJ, PUNSHON G, KRIJGSMAN B, HAMILTON G, SEIFALIAN AM: A hybrid compliant vascular graft seeded with microvascular endothelial cells extracted from human omentum. Artif Organs 25: 974-982, 2001.

SANTOS MI, FUCHS S, GOMES ME, UNGER RE, REIS RL, KIRKPATRICK CJ: Response of micro- and macrovascular endothelial cells to starch-based fiber meshes for bone tissue engineering. Biomaterials 28: 240-248, 2007. 
SANTOS TC, MORTON TJ, MORITZ M, PFEIFER S, REISE K, MARQUES AP, CASTRO AG, REIS RL, VAN GRIENSVEN M: Vascular endothelial growth factor and fibroblast growth factor-2 incorporation in starch-based bone tissue-engineered constructs promote the in vivo expression of neovascularization mediators. Tissue Eng Part A 19: 834-848, 2013.

SATO Y, TERASHIMA M, KAGIWADA N, TUN T, INAGAKI M, KAKUTA T, SAITO A: Evaluation of proliferation and functional differentiation of LLC-PK1 cells on porous polymer membranes for the development of a bioartificial renal tubule device. Tissue Eng 11: 1506-1515, 2005.

SCHNABELRAUCH M, SCHARNWEBER D, SCHILLER J: Sulfated glycosaminoglycans as promising artificial extracellular matrix components to improve the regeneration of tissues. Curr Med Chem 20: 2501-2523, 2013.

SHELTON JC, BADER DL, LEE DA: Mechanical conditioning influences the metabolic response of cell-seeded constructs. Cells Tissues Organs 175: 140-150, 2003.

SHI Q, LI Y, SUN J, ZHANG H, CHEN L, CHEN B, YANG H, WANG Z: The osteogenesis of bacterial cellulose scaffold loaded with bone morphogenetic protein-2. Biomaterials 33: 6644-6649, 2012a.

SHI L, AID R, LE VISAGE C, CHEW SY: Biomimicking polysaccharide nanofibers promote vascular phenotypes: a potential application for vascular tissue engineering. Macromol Biosci 12: 395-401, $2012 \mathrm{~b}$.

SHOKRGOZAR MA, MOTTAGHITALAB F, MOTTAGHITALAB V, FAROKHI M: Fabrication of porous chitosan/poly(vinyl alcohol) reinforced single-walled carbon nanotube nanocomposites for neural tissue engineering. J Biomed Nanotechnol 7: 276-784, 2011.

SILVA-CORREIA J, ZAVAN B, VINDIGNI V, SILVA TH, OLIVEIRA JM, ABATANGELO G, REIS RL: Biocompatibility evaluation of ionic- and photo-crosslinked methacrylated gellan gum hydrogels: in vitro and in vivo study. Adv Healthc Mater 2: 568-575, 2013.

STRANGE DG, OYEN ML: Composite hydrogels for nucleus pulposus tissue engineering. J Mech Behav Biomed Mater 11: 16-26, 2012.

TAGLER D, TU T, SMITH RM, ANDERSON NR, TINGEN CM, WOODRUFF TK, SHEA LD: Embryonic fibroblasts enable the culture of primary ovarian follicles within alginate hydrogels. Tissue Eng Part A 18: 1229-1238, 2012.

TUZLAKOGLU K, SANTOS MI, NEVES N, REIS RL: Design of nano- and microfiber combined scaffolds by electrospinning of collagen onto starch-based fiber meshes: a man-made equivalent of natural extracellular matrix. Tissue Eng Part A 17: 463-473, 2011.

ULERY BD, NAIR LS, LAURENCIN CT: Biomedical applications of biodegradable polymers. J Polym Sci B Polym Phys 49: 832-864, 2011.

VANDEVORD PJ, MATTHEW HW, DeSILVA SP, MAYTON L, WU B, WOOLEY PH: Evaluation of the biocompatibility of a chitosan scaffold in mice. J Biomed Mater Res 59: 585-590, 2002.

VANDROVCOVÁ M, DOUGLAS T, HAUK D, GRÖSSNER-SCHREIBER B, WILTFANG J, BAČÁKOVÁ L, WARNKE PH: Influence of collagen and chondroitin sulfate (CS) coatings on poly-(lactide-co-glycolide) (PLGA) on MG 63 osteoblast-like cells. Physiol Res 60: 797-813, 2011.

VERMA P, VERMA V, RAY P, RAY AR: Agar-gelatin hybrid sponge-induced three-dimensional in vitro 'liver-like' HepG2 spheroids for the evaluation of drug cytotoxicity. J Tissue Eng Regen Med 3: 368-376, 2009.

VIGETTI D, VIOLA M, KAROUSOU E, GENASETTI A, RIZZI M, CLERICI M, BARTOLINI B, MORETTO P, DE LUCA G, PASSI A: Vascular pathology and the role of hyaluronan. ScientificWorldJournal 8: 1116-1118, 2008.

WAGNER M, KIAPUR N, WIEDMANN-AL-AHMAD M, HÜBNER U, AL-AHMAD A, SCHÖN R, SCHMELZEISEN R, MÜLHAUPT R, GELLRICH NC: Comparative in vitro study of the cell proliferation of ovine and human osteoblast-like cells on conventionally and rapid prototyping produced scaffolds tailored for application as potential bone replacement material. J Biomed Mater Res A 83: 1154-1164, 2007.

WAN LQ, JIANG J, MILLER DE, GUO XE, MOW VC, LU HH: Matrix deposition modulates the viscoelastic shear properties of hydrogel-based cartilage grafts. Tissue Eng Part A 17: 1111-1122, 2011.

WANG X, YAN Y, XIONG Z, LIN F, WU R, ZHANG R, LU Q: Preparation and evaluation of ammonia-treated collagen/chitosan matrices for liver tissue engineering. J Biomed Mater Res B Appl Biomater 75: 91-98, 2005. 
WEIDENBECHER M, HENDERSON JH, TUCKER HM, BASKIN JZ, AWADALLAH A, DENNIS JE: Hyaluronanbased scaffolds to tissue-engineer cartilage implants for laryngotracheal reconstruction. Laryngoscope 117: 1745-1749, 2007.

WIPPERMANN J, SCHUMANN D, KLEMM D, KOSMEHL H, SALEHI-GELANI S, WAHLERS T: Preliminary results of small arterial substitute performed with a new cylindrical biomaterial composed of bacterial cellulose. Eur J Vasc Endovasc Surg 37: 592-596, 2009.

WU J, DU Y, MANN MM, YANG E, FUNDERBURGH JL, WAGNER WR: Bioengineering organized, multilamellar human corneal stromal tissue by growth factor supplementation on highly aligned synthetic substrates. Tissue Eng Part A 19: 2063-2075, 2013.

XU T, JIN J, GREGORY C, HICKMAN JJ, BOLAND T: Inkjet printing of viable mammalian cells. Biomaterials 26: 93-99, 2005.

YAMAMOTO M, JAMES D, LI H, BUTLER J, RAFII S, RABBANY S: Generation of stable co-cultures of vascular cells in a honeycomb alginate scaffold. Tissue Eng Part A 16: 299-308, 2010.

YAN S, ZHANG Q, WANG J, LIU Y, LU S, LI M, KAPLAN DL: Silk fibroin/chondroitin sulfate/hyaluronic acid ternary scaffolds for dermal tissue reconstruction. Acta Biomater 9: 6771-6782, 2013.

YE L, WU X, DUAN HY, GENG X, CHEN B, GU YQ, ZHANG AY, ZHANG J, FENG ZG: The in vitro and in vivo biocompatibility evaluation of heparin-poly( $\varepsilon$-caprolactone) conjugate for vascular tissue engineering scaffolds. J Biomed Mater Res A 100: 3251-3258, 2012.

YU J, WANG A, TANG Z, HENRY J, LI-PING LEE B, ZHU Y, YUAN F, HUANG F, LI S: The effect of stromal cell-derived factor-1 $\alpha$ /heparin coating of biodegradable vascular grafts on the recruitment of both endothelial and smooth muscle progenitor cells for accelerated regeneration. Biomaterials 33: 8062-8074, 2012.

ZAHEDMANESH H, MACKLE JN, SELLBORN A, DROTZ K, BODIN A, GATENHOLM P, LALLY C: Bacterial cellulose as a potential vascular graft: Mechanical characterization and constitutive model development. J Biomed Mater Res B Appl Biomater 97: 105-113, 2011.

ZAVAN B, VINDIGNI V, LEPIDI S, IACOPETTI I, AVRUSCIO G, ABATANGELO G, CORTIVO R: Neoarteries grown in vivo using a tissue-engineered hyaluronan-based scaffold. FASEB J 22: 2853-2861, 2008.

ZELLNER J, MUELLER M, BERNER A, DIENSTKNECHT T, KUJAT R, NERLICH M, HENNEMANN B, KOLLER M, PRANTL L, ANGELE M, ANGELE P: Role of mesenchymal stem cells in tissue engineering of meniscus. J Biomed Mater Res A 94: 1150-1161, 2010.

ZHOU H, XU HHK: The fast release of stem cells from alginate-fibrin microbeads in injectable scaffolds for bone tissue engineering. Biomaterials 32: 7503-7513, 2011.

ZIMMERMANN U, KLÖCK G, FEDERLIN K, HANNIG K, KOWALSKI M, BRETZEL RG, HORCHER A, ENTENMANN H, SIEBER U, ZEKORN T: Production of mitogen-contamination free alginates with variable ratios of mannuronic acid to guluronic acid by free flow electrophoresis. Electrophoresis 13: 269-274, 1992. 